\title{
Necrosaurus or Palaeovaranus? Appropriate nomenclature and taxonomic content of an enigmatic fossil lizard clade (Squamata)
}

\section{Necrosaurus ou Palaeovaranus? Nomenclature appropriée et contenu systématique d'un clade énigmatique de lézards fossiles (Squamata)}

\author{
Georgios L. Georgalis a,b,* \\ a Department of Geosciences, University of Fribourg, Chemin du Musée 6, 1700 Fribourg, Switzerland \\ ${ }^{\mathrm{b}}$ Department of Earth Sciences, University of Torino, Via Valperga Caluso 35, 10125 Torino, Italy
}

\section{Keywords: \\ Squamata \\ Paleogene \\ Palaeovaranus \\ Necrosaurus \\ Taxonomy \\ Mots clés : \\ Squamata \\ Paléogène \\ Palaeovaranus \\ Necrosaurus \\ Taxonomie}

\begin{abstract}
A B S T R A C T
Necrosaurus cayluxi is an enigmatic lizard from the Paleogene of the Phosphorites of Quercy, France that was first mentioned in the 19th century. Although it is generally believed that Filhol was the author who established this taxon, I am herein demonstrating that authorship should in fact be attributed to Zittel, a fact that also influences not only its generic nomenclature, but also its appropriate type material. As such, the valid name for this taxon should be Palaeovaranus cayluxi and its holotype is a left maxilla. Additionally, Ophisauriscus eucarinatus from the middle Eocene of Geiseltal, Germany, another taxon that was previously assigned to Necrosaurus, is herein shown to be a nomen dubium, whereas Melanosauroides giganteus from the same locality, is considered a valid species and is recombined as Palaeovaranus giganteus comb. nov. The suggested changes in nomenclature also affect "Necrosauridae", a poorly defined clade of lizards from the Cretaceous-Paleogene of Europe, North America, and Asia. In order to maintain nomenclatural stability and define a monophyletic lineage, I am here establishing the new family Palaeovaranidae fam. nov., which includes solely the genus Palaeovaranus. The known occurrences of Palaeovaranus across the Paleogene of Western Europe are discussed.
\end{abstract}

\section{R É S U M É}

Necrosaurus cayluxi est un lézard énigmatique du Paléogène des Phosphorites du Quercy, France, qui a été mentionné pour la première fois au $19^{\mathrm{e}}$ siècle. Bien qu'il soit généralement admis que Filhol est l'auteur qui a établi ce taxon, je démontre ici que la paternité devrait en fait en être attribuée à Zittel, ce qui influence également non seulement la nomenclature générique, mais aussi le matériel type approprié. En tant que tel, le nom valide pour ce taxon devrait être Palaeovaranus cayluxi et son holotype est un maxillaire gauche. En outre, Ophisauriscus eucarinatus de l'Éocène Moyen de Geiseltal, Allemagne, autre taxon précédemment assigné à Necrosaurus, est considéré comme étant un nomen dubium, tandis que Melanosauroides giganteus de la même localité est considéré comme une espèce valable et est recombinée comme Palaeovaranus giganteus comb. nov. Les changements suggérés dans la nomenclature affectent également les " Necrosauridae ", un clade mal défini de lézards du Crétacé-Paléogène d'Europe, d'Amérique du Nord et d'Asie. Afin de maintenir la stabilité de la nomenclature et de définir une lignée monophylétique, j'établis ici la nouvelle famille Palaeovaranidae fam. nov., qui comprend uniquement le genre Palaeovaranus. Les exemples connus de Palaeovaranus à travers le Paléogène d'Europe occidentale sont discutés.

* Department of Geosciences, University of Fribourg, Chemin du Musée 6, 1700

Fribourg, Switzerland.

E-mail address: georgios.georgalis@unifr.ch 


\section{Introduction}

The Phosphorites of Quercy ("Phosphorites du Quercy") in southern France have been known since the 19th century and have yielded a large array of fossil vertebrate finds that span stratigraphically from the early Eocene (MP 8+9) until the early Miocene (MN 3), though the majority of the respective fossiliferous localities ranges between the late middle Eocene (MP 16) and the late Oligocene (MP 28) (Rage, 2006; Rage and Augé, 2015). Among this bulk of material, the French palaeontologist Henri Filhol mentioned in a series of papers the presence of a large lizard and noted strong resemblance with modern monitor lizards (Varanidae) (Filhol, 1873, 1876, 1877a,b,c). Curiously, Filhol used a single specific epithet but three different generic names for this animal in an array of subsequent papers: Palaeosaurus cayluxi, Necrosaurus cayluxi, and Palaeovaranus cayluxi (Filhol, 1873, 1876, 1877a,b,c)! The genus name Necrosaurus is the most widely accepted one in modern literature and it is currently considered that it is not a varanid but rather represents a more distantly related form (Estes, 1983; Augé, 2005). This taxonomic view is also complemented by additional finds from the Paleogene of Europe and even a new family, Necrosauridae, was established in order to encompass them and denote their distinctiveness (Hoffstetter, 1943; Estes, 1983; Augé, 2005). However, by studying the primary literature and the 19th century papers mentioning this enigmatic reptile from Quercy, I am here demonstrating that the current nomenclature surrounding Necrosaurus is erroneous and that this affects also the identification of the type material and the taxonomic content of this genus.

Institutional Abbreviations: AMNH, American Museum of Natural History, New York, USA; BSPG, Bayerische Staatssammlung für Paläontologie und historische Geologie, Munich, Germany; GMH, Geiseltalmuseum of Martin-Luther Universität Halle-Wittenberg, now referred to as the Geiseltalsammlung, housed as part of the Zentralmagazin Naturwissenschaftlicher Sammlungen, Halle, Germany; HNHM, Hungarian Natural History Museum, Budapest,
Hungary; MFGI, Magyar Földtani és Geofizikai Intézet, Budapest, Hungary; MNHN, Muséum national d'Histoire naturelle, Paris, France; NHMUK, Natural History Museum, London, United Kingdom.

\section{Necrosaurus cayluxi or Palaeovaranus cayluxi?}

The first mention of a "necrosaurid" lizard was originally made by Filhol (1873) who introduced the name Palaeosaurus cayluxi for fossil remains from the Phosphorites of Quercy, France. In that short contribution, Filhol (1873:89) only mentioned that this animal was of large size ("un Lézard égalant l'Iguane") and that its skeletal remains resembled those of extant varanids ("une analogie remarquable avec l'ancien genre Monitor de Cuvier"), without, however, mentioning any character denoting this resemblance. In any case, the original generic name Palaeosaurus was already preoccupied by the, now considered indeterminate archosaur, Palaeosaurus Riley and Stutchbury, 1836. Three years later, Filhol (1876) provided another name, Necrosaurus cayluxi, for this taxon, referring also to this a fragment of a dentary ("une portion de maxillaire inférieur"), and stated again the resemblance of this taxon with extant varanids ("qui me paraissait avoir de grandes affinités, d'après les os des membres que j'avais pu étudier, avec le genre Monitor") (Filhol, 1876:27). The following year, in three almost identical papers, Filhol (1877a,b,c) again provided a new name, Palaeovaranus cayluxi, and figured the respective material (a partial dentary and a femur) for the first time (Fig. 1A). However, he still did not describe the material and only considered this lizard as having close affinities with extant varanids ("Sauriens très-voisins des Varans et des Monitor"), whereas at the same time he also speculated close and probable conspecific affinities with another Quercy lizard, "Varanus? margaritiferus" (an incorrect spelling of Varanus margariticeps Gervais, 1876, now considered an indeterminate glyptosaurine anguid [Augé, 2005]) (Filhol, 1877a,b,c).

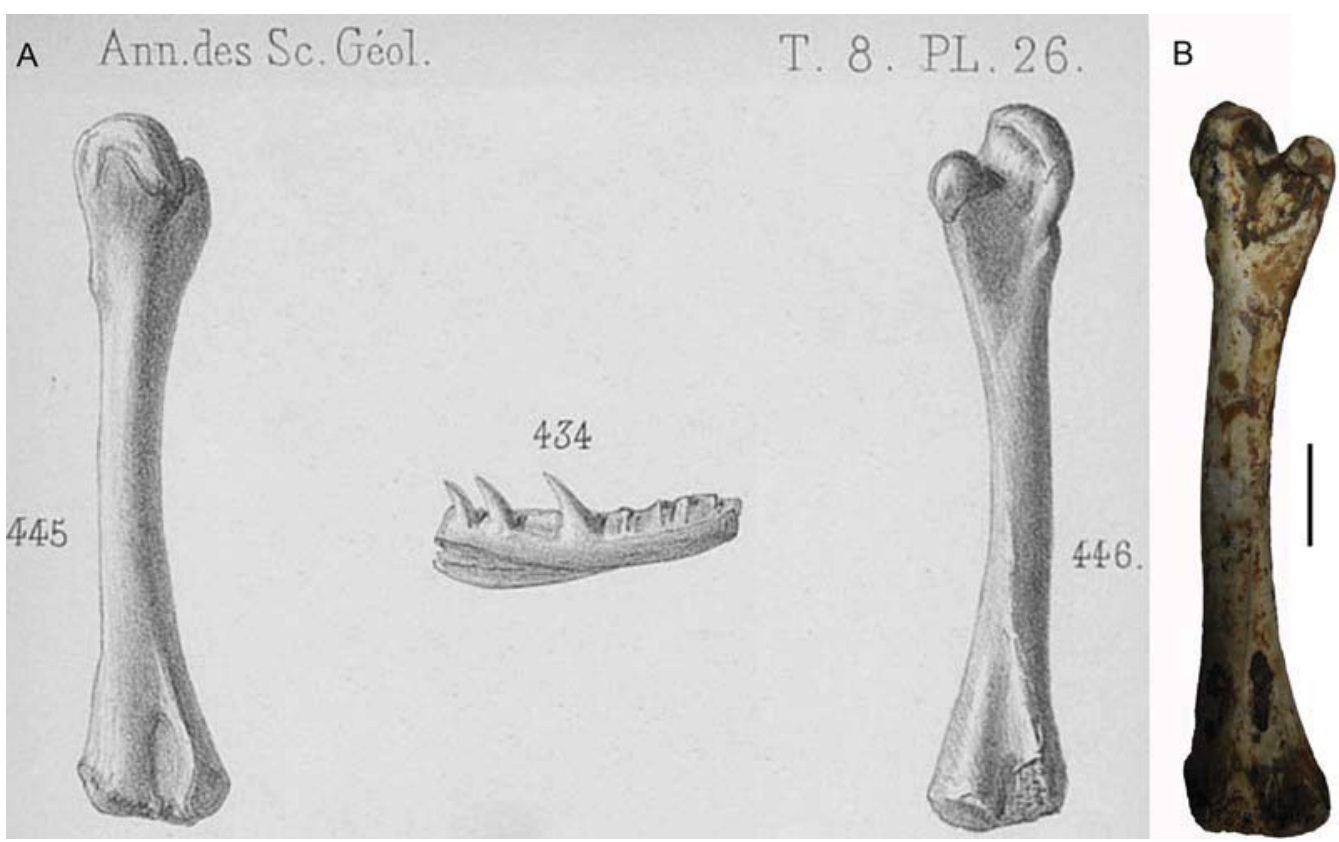

Fig. 1. The originally figured dentary and femur of "Palaeovaranus cayluxi" taken from Filhol's (1877a: plate 26) lithograph, herein referred to Palaeovaranus sp. (A). The same exactly lithograph was also featured in Filhol (1877b,c). Femur MNHN.F.QU17626, most probably representing the same specimen as the femur in Filhol's (1877a, b, c) lithograph (B). Scale bar $=1 \mathrm{~cm}$. Photograph by G. Georgalis, courtesy of MNHN.

Figures du dentaire et du fémur de "Palaeovaranus cayluxi » extraites de la planche lithographique de Filhol (1877a : planche 26), rapportés ici à Palaeovaranus sp. (A). La même planche lithographique a également été publiée dans Filhol (1877b,c). Fémur MNHN.F.QU17626, représentant probablement le même spécimen que le fémur dans la lithographie de Filhol $(1877 a, b, c)(B)$. Barre d'échelle $=1 \mathrm{~cm}$. Photographie par G. Georgalis, autorisation de MNHN. 



Fig. 2. The holotype of Palaeovaranus cayluxi (originally kept in BSPG, now probably lost) as being figured in the original lithograph of Zittel (1887-1890) (A) and the photograph of Fejérváry (1935) (B), (C). Note that the specimen in (A) seems like a right (and not left) maxilla, but it is in fact the reverse image, as is the common practice in lithography. (A), (B) represent the lingual view and (C) represents the labial view. Scale bar=1 cm, adapted according to Fejérváry's (1935) measurements.

L'holotype de Palaeovaranus cayluxi (initialement conservé au BSPG, probablement perdu maintenant), tel qu'il est figuré dans la lithographie originale de Zittel (1887-1890) (A) et la photographie de Fejérváry (1935) (B), (C). Noter que le spécimen en (A) semble être un maxillaire droit (et non gauche), mais c'est en fait une image inversée, pratique courante en lithographie. $(A),(B)$ représentent la vue linguale et $(C)$ représente la vue labiale. Barre d'échelle = $1 \mathrm{~cm}$, adaptée selon les mesures de Fejérváry (1935).

It is thus obvious, that in his first two papers, Filhol (1873, 1876) failed to provide any kind of even a brief description, definition, or indication to a previously published description, which are the minimum requirements for availability of zoological names in publications before 1931 (ICZN, 1999:Article 12.1). Indeed, the identification of a single specimen as a dentary (Filhol, 1876) or a general comment about the large size of a lizard (Filhol, 1873) cannot be considered descriptions, neither also the fact that the author constantly noted resemblance of his taxon with modern varanids. Regarding Filhol's (1877a,b,c) papers, which were the only that provided figures of the material, they still contained no description or definition. According to ICZN (1999:Article 12.2.7) though, an illustration of the material consists indeed of an indication for publications prior to 1931, and as such this could fulfill the minimum requirements of ICZN (1999) for availability of the name Palaeovaranus cayluxi that he suggested. However, by expressing his assumption that his taxon could probably be conspecific with Varanus margaritiferus (sic) and not a distinct form, Filhol (1877a, b, c) still failed also to render Palaeovaranus cayluxi available, as the author was uncertain about its validity, a criterion that is obligatory for ICZN (1999:Article 11.5), which clearly states that "[t]o be available, a name must be used as valid for a taxon when proposed, unless it was first published as a junior synonym and subsequently made available under the provisions of Article 11.6.1". Note also that Article 11.6.1 about availability of names originally introduced as junior synonyms, cannot apply in this case, as Filhol (1877a,b,c) did not formally render his Palaeovaranus cayluxi as a synonym of Varanus margaritiferus (sic). Therefore, all the three names created by Filhol for this animal do not fulfill the minimum requirements of ICZN (1999:Article 12.1) for availability of zoological names established prior to 1931. Accordingly, Palaeosaurus Filhol 1873, Necrosaurus Filhol 1876, Palaeovaranus Filhol 1877a,b,c, Palaeosaurus cayluxi Filhol, 1873, Necrosaurus cayluxi Filhol 1876, and Palaeovaranus cayluxi Filhol 1877a,b,c, are all nomina nuda and no attribution of these genera or the species epithet "cayluxi" to Filhol can be made.

Richard Lydekker further complicated the taxonomic status of this lizard, as he initially briefly mentioned that Filhol had described an imperfect mandibular ramus from the late Eocene of Quercy under the name Palaeovaranus cayluxi (Lydekker, 1886), whereas soon after, and during a single year, he proposed two different taxonomic opinions regarding its affinities and validity: one suggesting that Palaeovaranus cayluxi is a valid taxon with clear varanid affinities (Lydekker, 1888b) and one considering the former as synonymous with Varanus (his Placosaurus) margariticeps (Lydekker, 1888a). In his both contributions though, he rejected varanid affinities for the Filhol's (1877a,b,c) originally figured femur (Lydekker, 1888a, b). Interestingly also, Lydekker (1888a:279) described and figured additional vertebrae from Quercy housed at NHMUK, which he referred to Placosaurus margariticeps, but which have since been referred indeed to Palaeovaranus cayluxi (as Necrosaurus cayluxi)
(Hoffstetter, 1943; Augé, 2005). Accordingly, although Lydekker (1888a) provided description of these vertebrae, authorship of Palaeovaranus cayluxi cannot be attributed to him, as he considered the name invalid (junior synonym of Placosaurus margariticeps) (ICZN, 1999:Article 11.5). In a similar way, his other same year's publication (Lydekker, 1888b) failed also to comply with the rules of ICZN (1999) for availability of names prior to 1931, as this provided no description, definition or indication. This applies also to the first mention of Palaeovaranus cayluxi by this author (Lydekker, 1886), as his mention that Filhol had described this taxon cannot be an indication according to ICZN (1999), due to the fact that the French author had never in fact described it. It is worth noting that at the same year with Lydekker's (1888a, b) publications, a brief mention about Palaeovaranus cayluxi was also made by Weithofer (1888), but this still also lacked any kind of description, definition or indication.

The first formal description that treated this species as valid was only provided by Zittel (1887-1890), who briefly described and figured a maxilla (in lingual view) from "Labenque" (an erroneous spelling for the village of Lalbenque) under the name Palaeovaranus cayluxi (his fig. 540; this paper, Fig. 2A). Zittel (1887-1890:609) noted again resemblance with Varanus and only briefly described the shape of teeth of the maxilla as strong, sharply pointed and slightly curved ("welche sich durch kräftige, scharf zugespitzte und etwas gekrümmte, an der Basis gestreifte Zähne auszeichnet”). Nevertheless, this rather brief description complies with the minimum requirements of ICZN (1999:Article 12.1) for availability of zoological names established prior to 1931 for nomenclatural purposes. Therefore, Zittel (1887-1890) was the first to make the name available for this fossil lizard from France. The same author also tentatively referred to the same taxon an axis and an anterior caudal vertebra (Zittel, 1887-1890).

The fact that Zittel was the author who made the name available remained largely unnoticed by most subsequent workers who attributed authorship to Filhol but nevertheless, until the early 1940's, they utilized the name Palaeovaranus cayluxi (Roger, 1898; Eastman, 1902; De Stefano, 1903, 1905; Nopcsa, 1908; Broili, 1911; Boulenger, 1918; Gilmore, 1928; Fejérváry, 1935; Kuhn, 1939a, b, 1940b; Romer, 1945), with only few exceptions (Fejérváry, 1918; Dunn, 1927). Roger (1898) made a brief mention on Palaeovaranus cayluxi and continued to refer the taxon to varanids. In the English translation of Zittel's great compendium, Eastman (1902) reproduced the lithograph of Zittel's (1887-1890) maxilla of Palaeovaranus cayluxi and mentioned it among the other then known fossil lizards from Quercy. De Stefano (1903) used the generic name Palaeovaranus for "cayluxi", and he further established another taxon of this genus, Palaeovaranus filholi, on the basis of abundant cranial, vertebral and appendicular material, also from Quercy. The same author continued to use the name Palaeovaranus on his palaeoherpetofaunal lists of Quercy in his subsequent article two years later (De Stefano, 1905). Nopcsa (1908) also used 
the generic name Palaeovaranus but challenged the specific distinction of $P$. filholi from $P$. cayluxi, although he did not formally synonymize them. Broili (1911) also used the name Palaeovaranus cayluxi, reproduced the original lithograph of Zittel's (1887-1890) figured maxilla, and mentioned that this taxon is the oldest member of Varanidae. A brief mention on Palaeovaranus cayluxi was also made by Boulenger (1918), with comments on its affinities with Varanus margariticeps. In his first important monograph on varanoid lizards, Fejérváry (1918) considered P. cayluxi as belonging to Varanus and he further reinstated the status of the original right femur as belonging to a varanid. He also provided a new drawing of Zittel's (1887-1890) maxilla whereas he additionally, significantly expanded the stratigraphic distribution of this taxon by tentatively referring to it material from the middle Miocene of La Grive, France (Fejérváry, 1918), which was, however, subsequently shown to pertain to a true varanid (Varanus cf. hofmanni of Hoffstetter, 1969). It seems that, for some reason, Fejérváry (1918) considered that Filhol had indeed described this taxon and that is why he attributed authorship to the French author, although in the same manuscript he admitted that Filhol made "a study of very superficial nature, not even containing a real, particular description of the fossils" [Fejérváry, 1918:350]. Following the view of Fejérváry (1918), the generic attribution of "cayluxi" to Varanus was also followed by Dunn (1927). Nevertheless, Fejérváry reassessed his initial taxonomic opinion, and in his subsequent, posthumous, large treatise on monitor lizards, he used the binomen Palaeovaranus cayluxi for this lizard from Quercy (Fejérváry, 1935). He described this taxon in extensive detail, provided an approximate size estimation (average total length around $1.2 \mathrm{~m}$ ) and even a life reconstruction of the animal, and among the new material he referred to it, which comprised several dentaries, maxillae, ribs and appendicular elements, he distinguished also the original maxilla of Zittel, for which he provided the first photographs (Fejérváry, 1935) (his figs. 1, 2 on plate 10; this paper, Fig. 2B, C). He furthermore provided more detailed locality data for the respective material, mentioning that it originates from "Escamps near Lalbenque, (Dep. Lot), Quercy, Caylux (Dep. Tarn-et-Garonne), France" (Fejérváry, 1935:57), a locality that is now known to pertain to the late Eocene (MP 19) (Augé, 2005). Fejérváry (1935) also mentioned that this material of Palaeovaranus cayluxi that he described was labeled into the collections of BSPG under the binomen "Palaeovaranus cadurcensis", which is of course not an available name (ICZN, 1999:Article 12.3), and as such, should not be further taken into consideration. Gilmore (1928) briefly referred to Palaeovaranus cayluxi by noting the strong resemblance in tooth morphology between the Quercy taxon and his new Cretaceous North American species Parasaniwa wyomingensis. The same author also mentioned Palaeovaranus (using no species epithet) few years layer and compared the curvature of its teeth with that of his new taxon Provaranosaurus acutus Gilmore, 1942, from the Paleocene of Wyoming (Gilmore, 1942). Weigelt (1929) tentatively referred nineteen vertebrae from the Eocene of Geiseltal (Quarry “Cecilie I [MP 13/?14]), Germany, to Palaeovaranus (mentioning no species epithet), but this material was later realized by Kuhn (1939a) to belong to a booid snake (after my personal observation of this material [GMH CeI-5837-1926] I fully concur with its snake affinities). Kuhn (1939a,b, 1940b) and Romer (1945) were the last authors who treated Palaeovaranus as the valid generic name for this lizard, but nevertheless, they later both changed their opinion and used Necrosaurus as well (Romer, 1956; Kuhn, 1963), apparently influenced from the work of Hoffstetter (1943) (see below). Interestingly, Kuhn (1939a) considered that the vertebrae of Palaeovaranus share a rather similar morphology to those of the booid snake Paleryx and corrected the above-mentioned initial identification of Weigelt (1929) for the vertebrae from Geiseltal. Kuhn (1940b) also figured two additional specimens (a maxillary fragment and a partial dentary) from Quercy (his plates 9.12 and
10.5) that he referred to Palaeovaranus cayluxi, although he stated the possibility that they could pertain to the North American genus Parasaniwa Gilmore, 1928.

Judging from the above, Palaeovaranus was treated as the valid genus name for this taxon for the first four decades of the 20th century. However, on a rather vague statement and a misconception that Filhol's works included descriptions, the prominent squamate researcher Robert Hoffstetter suggested that the appropriate generic name for this lizard should be Necrosaurus and not Palaeovaranus. In fact, the only nomenclatural comment that Hoffstetter (1943) provided was that the initial proposed Filhol's genus name, Palaeosaurus, was preoccupied, and as such, the second chronologically provided Filhol's name, Necrosaurus, should have immediate priority. Nevertheless, Hoffstetter (1943) was the first to recognize the high distinctiveness between Necrosaurus cayluxi and Varanus spp. and he established a new family, Necrosauridae, to accommodate the former taxon. He summarized all the up to then known occurrences of "necrosaurids", and he further assigned the vertebrae figured by Lydekker (1888a) as Placosaurus margariticeps and a caudal vertebra previously referred to Iguana europaea by De Stefano (1903) to Necrosaurus. However, due to this nomenclatural misconception, the name Palaeovaranus was never again treated as valid ever since, and Necrosaurus was chosen as the appropriate generic name by all subsequent workers (e.g. Hoffstetter, 1954, 1955, 1962a,b, 1969; McDowell and Bogert, 1954; Romer, 1956; Hecht and Hoffstetter, 1962; Kuhn, 1963; Haubold, 1977; Meszoely et al., 1978; Rage, 1978, 1984a, b, 1988, 2013; Rage and Ford, 1980; Rieppel, 1980; Estes, 1983; Borsuk-Białynicka, 1984; Carroll, 1988; Augé, 1990a, b, 1993, 2003, 2005; Alifanov, 1993; Rage and Augé, 1993; Cifelli and Nydam, 1995; Norell and Gao, 1997; Gao and Norell, 1998; Cifelli et al., 1999; Nydam, 2000; Rieppel et al., 2007; Conrad, 2008; Conrad et al., 2008, 2011, 2014; Augé and Smith, 2009; Klembara and Green, 2010; Laurent et al., 2010; Rage and Augé, 2010, 2015; Hong-Yu and Norell, 2013; Smith and Gauthier, 2013; Smith, 2017).

Considering that the name Necrosaurus cayluxi was the prevailing one that has been applied to this taxon over the last seven decades, one would regard that a petition to ICZN in order to maintain that name would be the appropriate way to deal with this nomenclatural problem. However, besides the fact that the genus name Necrosaurus is in fact unavailable, it should be noted that among the number of papers that have mentioned the name Necrosaurus cayluxi, only few have in fact dealt with this taxon and included new material of it and/or descriptions or designation of differentiating characters (Hoffstetter, 1969; Rage, 1978; Estes, 1983; Augé, 2005; Augé and Smith, 2009). Furthermore, one of the most complete descriptions of this lizard remains still that of Fejérváry (1935) who used the binomen Palaeovaranus cayluxi and also provided detailed figures and photographs of the material. Also, the left maxilla figured by Zittel (1887-1890) and photographed also in Fejérváry (1935) provides more important taxonomic characters than Filhol's (1877a,b,c) dentary (see below). Additionally, as Zittel (1887-1890) and especially Fejérváry (1935) were more precise with giving locality data for this specimen, it seems that it most probably originates from the well-dated Escamps locality which pertains to the late Eocene MP 19 Mammal Zone, although it cannot be excluded that it well originates from some other locality in the vicinity of the village of Escamps (e.g. Rosières 2 and 3 that are also MP 19, but Rosières 5 is MP 17) (J.-C. Rage, personal communication, July 2017). It is worth noting that Zittel (1887-1890) provided also Escamps as the locality of another tetrapod from Quercy, his new salamander taxon Megalotriton filholi Zittel, 1887-1890, and this precise geographic provenance is also followed in modern literature (Rage and Augé, 2015). In any case, Zittel's (1887-1890) figured maxilla of Palaeovaranus cayluxi seems 
to be much more precisely geographically and stratigraphically defined in comparison with the vague origins of Filhol's (1873, 1876, 1877a,b,c) material.

For all the above-mentioned reasons, I here consider that a petition to ICZN for maintaining the name Necrosaurus cayluxi is not needed and in fact, would only further cause taxonomic problems with the diagnosis of the taxon and even its validity. I instead attribute authorship of both the genus Palaeovaranus and the specific epithet "cayluxi" to Zittel (1887-1890). As such, the proper name for the genus should be Palaeovaranus Zittel, 1887-1890 and for the species Palaeovaranus cayluxi Zittel, 1887-1890. As a consequence, Palaeovaranus cayluxi is the type species of the genus Palaeovaranus.

The herein suggested attribution of the genus and species name Palaeovaranus cayluxi to Zittel (1887-1890) inevitably affects also the type material of this taxon. Contrary to the prevailing aspect that Filhol's figured dentary and femur (Fig. 1A) represent the type material of this taxon, the "true" holotype is Zittel's (1887-1890) figured left maxilla (Fig. 2). An additional axis and an anterior caudal vertebra that were figured in the same publication by Zittel (1887-1890:603) were only tentatively referred by him to this taxon, as ?Palaeovaranus cayluxi, so, due to his uncertainty, they should not therefore be considered as belonging to the type series of the species. The holotype left maxilla was further figured again by Eastman (1902), Broili (1911), Fejérváry (1918, 1935), and Estes (1983). Furthermore, Fejérváry (1935) was the first to provide photographs of the holotype maxilla and depicted also the labial view of the specimen, noting also inaccuracies in the original lithograph of Zittel (1887-1890). Such inaccuracies in the original lithographs are not rare in palaeontological papers from the 19th century, as has also been demonstrated for various fossil vertebrate clades, among others, fossil snakes (Georgalis et al., 2016) and turtles (Anquetin and Joyce, 2014; Georgalis and Joyce, 2017). Fejérváry (1935) also provided for the first time detailed measurements for this specimen, whose preserved total length was $38.58 \mathrm{~mm}$. Unfortunately, the holotype maxilla cannot be located currently in the collections of BSPG where it was originally housed, so it is possible that the material was destroyed during the WW II (Oliver Rauhut, personal communication, July 2017). Alternatively, this specimen could still be in Hungary, as Fejérváry (1935) noted that he had taken it with him on loan from Munich on 1923. However, unfortunately it could not be located in the collections of neither HNHM, MFGI, nor the University of Pécs (Hungarian institutions that Fejérváry was affiliated) (Zoltán Szentesi, László Makádi, and Krisztina Sebe, personal communication, August 2017). Despite the fact that this specimen seems to be currently lost, I do not consider that the selection of a new one as the neotype is necessary, as the holotype was rather adequately figured and described, especially in the works of Fejérváry $(1918,1935)$. On the other hand, Filhol's (1877a,b,c) figured partial dentary and right femur (Fig. 1A), the previously supposed syntypes of Palaeovaranus cayluxi, are part of the old, not well-dated, Quercy collections and are further not taxonomically informative, hindering thus the taxonomic validity of the taxon. Indeed, the lithograph of the dentary (Filhol, 1877a,b,c) shows a rather incomplete specimen and only in lingual view, whereas the figured right femur (Filhol, 1877a,b,c) also does not provide any important taxonomic information. The dentary also appears now to be lost (Klembara and Green, 2010), though it would not be surprising if it eventually emerges from the collections of AMNH, as is the case of the holotype of another Filhol's lizard, Pseudeumeces cadurcensis, which was only recently rediscovered there (Bolet et al., 2017). Regarding Filhol's femur, its lithograph is rather similar to one femur from Quercy that is currently housed in the collections of MNHN (MNHN.F.QU17626, labeled as "Necrosaurus cf. cayluxi"; personal observation, October 2016) and it is preliminarily identified as that specimen (Fig. 2B), especially taking into consideration the fact that there is only one damaged area and that this area occupies the same place on the specimen and on the lithograph (Jean-Claude Rage, personal communication, July 2017). I here tentatively consider both Filhol's specimens as representing an indeterminate species of Palaeovaranus and assign them to Palaeovaranus sp.

\section{Melanosauroides giganteus or Ophisauriscus eucarinatus?}

In a paper dealing with the fossil lizards from the well known middle Eocene locality of Geiseltal, Germany, Kuhn (1940b) described and named two purported large anguids, aff. Ophisauriscus (Melanosauroides) eucarinatus and Melanosauroides giganteus. This case seems strange even at a first glance, as Kuhn (1940b) treated his newly established genus name Melanosauroides firstly as a subgenus of his aff. Ophisauriscus and, in few pages later, as a valid, distinct genus name. Ophisauriscus eucarinatus was established on the basis of GMH CeIV-4021-1933, a hind limb with associated osteoderms (Fig. 3A), whereas another specimen (GMH CeIV-4054-1933) was also tentatively referred to the same taxon (Fig. 3B) (Kuhn, 1940b). This species was only rather briefly described, and only the holotype was figured (Kuhn, 1940b). To the contrary, Melanosauroides giganteus was established on a single, but much more complete specimen, GMH CeIII-4139-1933, a disarticulated skeleton, including skull elements (parietal, frontal, quadrate, maxilla, dentary, and jugal) (Fig. 4) and was more extensively described, discussed, and figured in the original publication (Kuhn, 1940b). It is worth noting also that the two type specimens were recovered from different quarries within Geiseltal and as such, they pertain to different ages: the holotype of Melanosauroides giganteus originated from the younger (MP 13/?MP 14) Quarry "Cecilie III", whereas the holotype and the other referred specimen of Ophisauriscus eucarinatus from the older (MP 13) Quarry “Cecilie IV" (Haubold and Krumbiegel, 1984).

Hoffstetter (1943) was the first to realize the "necrosaurid" affinities of Melanosauroides giganteus and he transferred this species into Necrosaurus, recombining it as Necrosaurus giganteus, but did not discuss at all Ophisauriscus eucarinatus. McDowell and Bogert (1954) also accepted congeneric affinities with Necrosaurus for Melanosauroides giganteus, but they constantly used the incorrect specific epithet "maximus" instead of "giganteus" throughout their text, apparently verbally confusing it with (the currently considered a glyptosaurine anguid) Melanosaurus maximus Gilmore, 1928, from the Eocene of the USA, which they also treated as a close relative of the German taxon. Nevertheless, these authors redescribed the type and only known specimen of Melanosauroides giganteus and highlighted important anatomical features, which they regarded as "shinisaur" characteristics (McDowell and Bogert, 1954). In a similar way to Hoffstetter (1943), McDowell and Bogert (1954) totally ignored Ophisauriscus eucarinatus. The "necrosaurid" affinities of "giganteus" also convinced Kuhn himself, who in a later paper used the binomen Necrosaurus giganteus, but still treated his "eucarinatus" as an anguid, under the binomen ?Ophisauriscus eucarinatus (Kuhn, 1963).

The first authors who compared both these two Geiseltal lizards were Haubold (1977) and Estes (1983). These authors regarded both Ophisauriscus eucarinatus and Melanosauroides giganteus as conspecific and continued to accept their "necrosaurid" affinities (Haubold, 1977; Estes, 1983). Among the two researchers, Haubold (1977) was the first to formally synonymize these two taxa and, as the first reviser, considered Necrosaurus giganteus as the senior synonym and valid name for this species, to which he also referred new cranial material from Geiseltal. However, in an act of nomenclatural inconsistency, Estes (1983) appealed only to page priority in order 
to render "eucarinatus" as the senior synonym of "giganteus", even though this criterion has no standing according to ICZN (1999) (see also Georgalis and Joyce, 2017 for a discussion). Estes (1983) also referred to "necrosaurids" another species from Geiseltal, Eosaniwa koehni, which was originally described as a varanid by Haubold (1977). Despite the fact that Haubold (1977) was the first reviser, the opinion of Estes (1983) has since been broadly followed by all subsequent authors who dealt with this form again under the combination Necrosaurus eucarinatus (e.g. Rage, 1988; Augé, 1993, 2005; Conrad, 2008) and even Haubold and Krumbiegel (1984) mentioned the page priority issue of the species epithet "eucarinatus" over "giganteus". The only exception to this synonymization was made by Borsuk-Białynicka (1984) who (probably unaware of Estes's [1983] work) followed Haubold (1977) and mentioned this taxon as Necrosaurus giganteus, though she casted doubts about its "necrosaurid" affinities.

This nomenclatural misconception that has also important taxonomic implications apparently arose from the influential status of Estes's (1983) compendium, which has served up to now as a standard reference point for squamate palaeontology. However, besides the erroneous usage of the page priority criterion that Estes (1983) applied to overrule the actions of Haubold (1977) as first reviser, the major point is that "eucarinatus" was founded upon a rather incomplete specimen that comprises no cranial elements, whereas the holotype of "giganteus" includes skull material

- that bears important diagnostic characters for defining the species. Indeed, all subsequent authors who referred new specimens to "eucarinatus" based their referral to shared resemblance among the skull remains (e.g. Augé, 2005), though these elements are only present on the holotype of "giganteus". My first hand observation of the above-mentioned specimens at the collections of GMH lead me to consider that the type of Ophisauriscus eucarinatus bears no diagnostic features at the species level and as such, I am here suggesting this taxon to be a nomen dubium. Nevertheless, the shape of the osteoderms on the type of O. eucarinatus bears the distinctive "necrosaur" morphology of these elements (Estes, 1983; Augé, 2005; see also Smith, 2017 for a discussion about similar osteoderm morphology present also in shinisaurid lizards) and the specimen thus represents an indeterminate species of Palaeovaranus, herein referred to as Palaeovaranus sp. The same seems to be also the case for GMH CeIV-4054-1933, which was referred to O. eucarinatus by Kuhn (1940b). This specimen is also a limb element with several osteoderms, is figured herein for the first time (Fig. 3B), and is also referred to as Palaeovaranus sp. To the contrary, Melanosauroides giganteus is indeed a valid taxon, with its holotype bearing evident "necrosaur" features on the maxilla, dentary, and shape of teeth. Accordingly, I am here recombining this taxon as Palaeovaranus giganteus comb. nov. Notably, the holotype of Palaeovaranus giganteus is one of the most complete specimens of the genus Palaeovaranus. It is worth noting that despite its name, in a bit sense of taxonomic and nomenclatural irony, Palaeovaranus giganteus is smaller than its congener Palaeovaranus cayluxi.

It is beyond the scope of this paper to redescribe Palaeovaranus giganteus and I simply refer here the diagnostic features provided by Augé (2005), Klembara and Green (2010), and Rage and Augé (2010) for their "Necrosaurus eucarinatus", which was in any case partially based on the holotype of Melanosauroides giganteus. As such, Palaeovaranus giganteus can be differentiated from Palaeovaranus cayluxi by the following characters: smaller size, higher tooth number, lateral margins of the parietal which do not meet to form a posterior sagittal ridge, parietal having a narrow extension of the table posteriorly, and osteoderms fused to the dorsal surface of the parietal.

\section{Palaeovaranidae fam. nov., an enigmatic Paleogene lizard clade}

Hoffstetter (1943) established his new family Necrosauridae to accommodate certain large European Paleogene lizards that possessed pointed and recurved ("caniniform") teeth. Varanoid affinities of necrosaurids were firstly challenged by McDowell and Bogert (1954) who considered them as shinisaurids (then nested within Xenosauridae), a suggestion that seemed to convince even Hoffstetter (1954) and only tentatively or partially followed by others (Romer, 1956; Kuhn, 1963; Haubold, 1977). In any case, "necrosaurids" were soon "taxonomically" returned to varanoids by the same author who coined the family name (Hoffstetter, $1962 \mathrm{~b})$, and there has since been a consensus, at least for their platynotan affinities: either nested within varanoids (e.g. Hecht and Hoffstetter, 1962; Hoffstetter, 1969; Estes, 1983; Carroll, 1988;

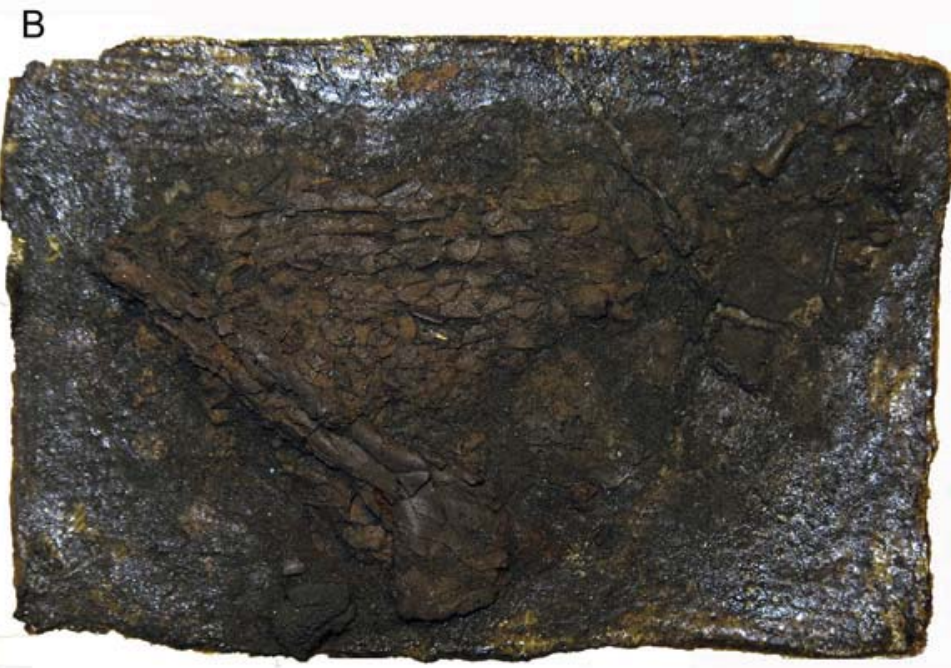

Fig. 3. Photographs of the holotype of Ophisauriscus eucarinatus (GMH CeIV-4021-1933) (A) and a specimen previously referred to this species (GMH CeIV-4054-1933) (B), both herein attributed to Palaeovaranus sp., from the middle Eocene of Geiseltal, Germany. Scale bar $=5 \mathrm{~cm}$. Photographs by G. Georgalis, courtesy of GMH.

Photographies de l'holotype d'Ophisauriscus eucarinatus (GMH CeIV-4021-1933) (A) et d'un spécimen précédemment affecté à cette espèce (GMH CeIV-4054-1933) (B), tous deux attribués dans le présent travail à Palaeovaranus sp., de l'Eocène moyen de Geiseltal, Allemagne. Barre d'échelle =5 cm. Photographies par G. Georgalis, autorisation de GMH. 



Fig. 4. Photograph of the holotype of Melanosauroides giganteus (GMH CelII-4139-1933) (herein Palaeovaranus giganteus) (A) from the middle Eocene of Geiseltal, Germany. Close up of the maxilla and associated vertebrae (B). Close up of the parietal (C). Scale bar $=5 \mathrm{~cm}$ (for A). Photographs by G. Georgalis, courtesy of GMH.

Photographie de l'holotype de Melanosauroides giganteus (GMH CeIII-4139-1933) (dans le présent travail: Palaeovaranus giganteus) (A) l'Éocène moyen de Geiseltal, Allemagne. Gros plan du maxillaire et des vertèbres associées (B). Gros plan du pariétal (C). Barre d'échelle =5 cm (Pour A). Photographies par G. Georgalis, autorisation de GMH.

Augé, 1990a, 2005; Carroll and Debraga, 1992; Conrad, 2008; Augé and Smith, 2009; Houssaye et al., 2011; Vitt and Caldwell, 2014; Georgalis et al., 2017), or simply representing a paraphyletic assemblage of platynotans (e.g. Borsuk-Białynicka, 1984; Pregill et al., 1986; Cifelli and Nydam, 1995; Lee, 1997; Norell and Gao, 1997; Gao and Norell, 1998; Molnar, 2004; Rieppel et al., 2007; Klembara and Green, 2010; Hong-Yu and Norell, 2013; Bolet, 2017).

The taxonomic content of "necrosaurids" was soon after modified in order to encompass also taxa from geographic areas outside Europe. Indeed, even upon its establishment, the Late Cretaceous North American Parasaniwa wyomingensis was already suggested to bear strong resemblance with Palaeovaranus cayluxi (Gilmore, 1928). Such a suggestion apparently influenced also Kuhn (1940b) who described and figured new material of Palaeovaranus cayluxi from Quercy but he stressed the possibility that these specimens could pertain to Parasaniwa. Hoffstetter (1969) also suspected that his European Necrosauridae were rather similar to Parasaniwa wyomingensis and another Late Cretaceous North American taxon, Paraderma bogerti Estes, 1964. Both of these North American forms were already placed into their own family, Parasaniwidae, by Estes (1964), but the same author soon reassessed his opinion and, in his monumental compendium of fossil lizards, he subsumed Parasaniwidae into Necrosauridae (Estes, 1983). With this taxonomic rearrangement, "necrosaurids" formally ceased to be an exclusively European lineage, but their geographic range was significantly expanded into North America, whereas their stratigraphic distribution went as back as the Cretaceous. This taxonomic action apparently led the way for recognizing more "necrosaurids" in the fossil record of different continents and different epochs. Characteristically, the Late Cretaceous Mongolian form Parviderma inexacta Borsuk-Białynicka, 1984, was also originally described as a "necrosaurid", whereas Ekshmer bissektensis Nessov, 1981, from the Late Cretaceous (Coniacian) of Uzbekistan, was subsequently referred to the same group (Nessov, 1997). Yadagiri (1986) described his new species Paikasisaurus indicus from the Early Jurassic of India, assigning it to Parasaniwidae (apparently ignoring the paper of Estes [1983]), but this taxon is based on extremely fragmentary dentary material and its taxonomic attribution cannot be evaluated. An additional form from the Early Cretaceous (Albian) of Utah has been referred to Necrosauridae by Cifelli and Nydam (1995), with these authors suggesting that this could eventually represent the oldest member of this clade. Besides the problematic Paikasisaurus indicus, all these chronologically and geographically disparate forms were mostly characterized by "subpleurodont" 
(sensu Hoffstetter, 1954), fang-like, and recurved teeth, oval and high keeled osteoderms, and, in several cases, dentition with plicidentine. In order to render a monophyletic Necrosauridae, Augé (2005) proposed a revised diagnosis for this clade, including only the European Paleogene genera Necrosaurus and Eosaniwa, but also the Asian Cretaceous Parviderma.

Considering that I here conclude that Necrosaurus is not an available name for zoological nomenclature, the name Necrosauridae is rendered invalid (ICZN, 1999:Article 11.7.1.1), and it is thus necessary to introduce a new name for the immediate clade typified by the genus Palaeovaranus Zittel, 1887-1890, and its type species Palaeovaranus cayluxi Zittel, 1887-1890. Following the ICZN (1999), I am herein introducing the new name Palaeovaranidae fam. nov., for which I am using a Linnean "family" rank for simplicity purposes. Taking into consideration that the species level taxonomy of the formerly called "necrosaurids" and their affinities within other squamates are still unresolved, I am here defining the monotypic Palaeovaranidae as including only the European Paleogene genus Palaeovaranus. As for the diagnosis and the differentiation of Palaeovaranidae from other lizards, I am herein following the one proposed by Augé and Smith (2009) for Necrosaurus, adding also characters from the recent studies of Klembara and Green (2010) and Rage and Augé (2015). Accordingly, both Palaeovaranidae and Palaeovaranus can be diagnosed on the basis of the combination of the following characters: presence of oval, keeled osteoderms, premaxilla with a long, arched nasal process, non-paired frontal, not narrowed between the orbits, non-paired parietal, no ridges on the ventral surface of the parietal, adductor musculature extending onto dorsal surface of parietal, sometimes with a sagittal crest, intramandibular septum being fused along its ventral border, teeth being trenchant, blade-like, recurved, tooth bases dilated, striated, with plicidentine, tooth replacement alternate and interdental, cervical vertebrae elongate, caudal vertebrae with no autotomic septa, caudal vertebrae with pedicles for articulation with chevron bones located very close to the condyle, and transverse processes of the caudal vertebrae slightly extending anteroposteriorly and being located more posteriorly than in anguines (Augé and Smith, 2009; Klembara and Green, 2010; Rage and Augé, 2015). However, I acknowledge that if future phylogenetic analysis demonstrates that the Cretaceous North American Parasaniwa shares indeed close relationships with the European Paleogene Palaeovaranus, then the name Parasaniwidae Estes, 1964, is available for that clade as it has priority.

The distribution of Palaeovaranidae and Palaeovaranus is confined from the early Eocene to the early Oligocene of Europe. The lineage seems to have become extinct shortly after the so called "Grande Coupure" that exterminated several European herpetofaunal elements at the Eocene-Oligocene boundary (Rage, 1984a, 2013; Augé, 2005). Two potential Paleocene records from Cernay, France (Hoffstetter, 1943, 1962b; Augé, 2005), and Walbeck, Germany (originally Saniwa aff. ensidens of Kuhn, 1940a; Augé, 1990b), have not been adequately described and their assignment to palaeovaranids should be only considered as tenuous. The new taxonomic scheme, which I am here suggesting, with Palaeovaranus cayluxi as the appropriate name over Necrosaurus cayluxi and Palaeovaranus giganteus being the only other valid referred species of this genus, necessitates an update in the nomenclature and identification of certain other "necrosaurid" occurrences. Palaeovaranus cayluxi is only known from France, with various records from the old, non precisely dated collections of Quercy (De Stefano, 1903; Fejérváry, 1935; Kuhn, 1940b; Augé, 1986, 2005), but also from the well-dated late Eocene localities of Sainte Néboule (MP 18) (Rage, 1978; Augé, 1986, 2005), Escamps (MP 19) (Zittel, 1887-1890; Augé, 1986, 2005), and Rosières B (MP 19) (Augé, 2005). In addition, a similar or even conspecific form that has been described as Necrosaurus cf. cayluxi from the middle Eocene (MP
16) of Le Bretou (Rage, 1988), is here tentatively referred to Palaeovaranus cf. cayluxi. As far as it concerns Palaeovaranus giganteus, apart from its holotype and the referred material from the middle Eocene (MP 13/14) of Geiseltal, Germany (Kuhn, 1940b; Haubold, 1977), this species is also known from the late Eocene of France (La Bouffie, MP 17 [Augé, 1986]; Les Pradigues, MP 17 [Augé, 1986, 2005]; Escamps, MP 19 [Augé, 1986, 2005; Rage, 2013]), and from the old, undated collections of Quercy (Augé, 1986, 2005). I have to admit, however, that the vast majority of all these referrals to the two Palaeovaranus species has been made mostly by using phenetic resemblance of the material and not a thorough phylogenetic analysis, so it has to be regarded as provisional.

In addition to the two valid species, Palaeovaranus cayluxi and $P$. giganteus, other indeterminate palaeovaranid material that cannot be assigned to the species level but can only be referred to as Palaeovaranus sp. is also known from the early Eocene of Belgium (Dormaal, MP 7 [Augé, 1990b, 2005]), the early Eocene of France (Condé-en-Brie, MP 8/9 [Augé, 2005]; La Borie, MP 8/9 [Laurent et al., 2010]), the early Eocene of Spain (Masia de l'Hereuet, MP 8+9 [Bolet, 2017]), the middle Eocene of France (Saint-Maximin, MP 13 [Duffaud and Rage, 1997]), the middle Eocene of Germany (Messel, MP 11 [Keller and Schaal, 1992]), the late Eocene of The United Kingdom (Totland Bay, MP 17 [Klembara and Green, 2010]; Headon Hill, MP 18 [Rage and Ford, 1980]; Osborne, MP 19 [Klembara and Green, 2010]; Hamstead, MP 20/21 [Klembara and Green, 2010]), the early Oligocene of Belgium (Boutersem, MP 21 [Augé and Smith, 2009]; Hoeleden, MP 21 [Hecht and Hoffstetter, 1962]; Hoogbutsel, MP 21 [Hecht and Hoffstetter, 1962]), and the early Oligocene of France (Mas de Got B, MP 22 [Augé, 1986, 2005]; Valbro, MP 22 [Rage and Augé, 2015]). To these, I am adding the original "necrosaurid" material of Filhol (1873, 1876, 1877a,b,c) and Lydekker (1888a) from the Old collections of Quercy, as also the type material of Odontomophis atavus Rochebrune, 1884, Palaeovaranus filholi De Stefano, 1903, and one of the paralectotypes (MNHN.F.QU16334) of Pylmophis gracilis Rochebrune, 1884, also from the old collections of Quercy, the above-mentioned Ophisauriscus eucarinatus Kuhn, 1940b, and material referred by Kuhn (1940b) to cf. Glyptosaurus hillsi, from the middle Eocene of Geiseltal, Germany, which all show palaeovaranid features, though not adequate to diagnose a taxon at the species level (Hoffstetter, 1946, 1955; Meszoely et al., 1978; Estes, 1983; Rage, 1984b; Augé, 2005). Odontomophis atavus was originally established as a scolecophidian snake on the basis of a dentary (Rochebrune, 1884) but it was subsequently demonstrated that it pertains to an indeterminate species of "Necrosaurus" (Hoffstetter, 1946, 1955; Rage, 1974, 1984b). Palaeovaranus filholi was established upon a large number of specimens, including a maxilla, mandibles, vertebrae, and appendicular elements, and this taxon was mostly differentiated from Palaeovaranus cayluxi by its shape and size of teeth and the shape of the glenoid cavity of their vertebrae (De Stefano, 1903), features that are highly variable within lizards. Indeed, the distinctiveness of Palaeovaranus filholi has since been strongly criticized (Nopcsa, 1908; Fejérváry, 1918; Estes, 1983; Augé, 2005), though I note that part of the maxillary and/or the mandibular type material could eventually have some taxonomic significance. In any case, it cannot be demonstrated whether the plethora of the syntypes of Palaeovaranus filholi belong indeed even to the same species, and the taxon could even represent a chimaera. This problem could be solved through the designation of a lectotype, but pending redescription of this material, I am refraining from acting so. Regarding Pylmophis gracilis, this taxon was established as a new snake species from Quercy on the basis of two articulated posteriormost trunk vertebrae, one dentary, and one "mummified" skin (Rochebrune, 1884). Nevertheless, it was subsequently shown by Rage $(1974,1981,1984 b)$ that the dentary that was part of the original type series belonged in fact to a lizard. The same author also designated one of the specimens 
as the lectotype (the two articulated posteriormost trunk vertebrae; MNHN.F.QU16335) of Pylmophis gracilis in order to resolve the chimaera status of this species and to maintain taxonomic stability (Rage, 1984b). In any case, judging from the published figure of Rochebrune (1884:figure 9 of his plate 2), which depicts the dentary only in labial view, it seems that this specimen could pertain to a palaeovaranid, although the teeth appear to be relatively more slender in comparison with other specimens of this clade. I provisionally refer this specimen to Palaeovaranus sp. As for the Geiseltal material that was tentatively referred to the North American taxon cf. Glyptosaurus hillsi by Kuhn (1940b), it consisted a specimen with vertebrae and osteoderms that was soon after attributed to Necrosaurus sp. by Meszoely et al. (1978) and subsequently to Necrosaurus eucarinatus by Estes (1983). I also consider this occurrence as an indeterminate species of Palaeovaranus. In all the above-mentioned occurrences, generic attribution to Palaeovaranus is mostly made by general, shared morphological features, and thus should not be considered as definite. Furthermore, special caution is needed when dealing with isolated finds, as shinisaurids have recently been described also from the Paleogene of Europe and they have similar osteoderms to those of palaeovaranids (Smith, 2017). Moreover, there are other purported occurrences of this genus that were mentioned by Augé (2005), but they lack any description, figures, or/and repository numbers, and so their taxonomic status cannot therefore be evaluated. Such records are omitted here from further consideration. Additionally, two other Eocene German taxa, Eosaniwa koehni Haubold, 1977, from Geiseltal, and Saniwa feisti Stritzke, 1983, from Messel, have been variously suggested to represent "necrosaurids" (Estes, 1983; Augé, 1990b, 2005; Rossmann, 2000; Conrad, 2008; Smith, 2017). A redescription of Eosaniwa koehni has recently demonstrated that it represents a derived varanoid (Rieppel et al., 2007). Regarding Saniwa feisti, this taxon has not yet been redescribed under a modern phylogenetic context, although in recent literature, its originally suggested varanid affinities (Stritzke, 1983) have been questioned, it has generally been considered as a "necrosaurid" (Augé, 1990b, 2005; Rossmann, 2000; Conrad, 2008), and was even referred under the combination Necrosaurus feisti by Smith (2017). They are both herein excluded from Palaeovaranus and Palaeovaranidae, though most probably they represent allied forms, especially the latter species, which could eventually pertain indeed to Palaeovaranus. Lastly, Alifanov (1993) reported the presence of Necrosaurus sp. from the late Paleocene of Tsagan-Hushu locality, Mongolia, whereas he further speculated that ecological competition with varanids drove Asian "necrosaurids" to their extinction by the middle Eocene. However, this material was never described and/or figured and as such, I consider its generic assignment as dubious and, in any case, the presence of Palaeovaranus in Asia is not justified on the basis of the current evidence.

Of course, the exact affinities and the precise systematic designation of Palaeovaranidae and Palaeovaranus are far from resolved. It is beyond the scope of this paper to address these issues, but nevertheless, the clarification of the appropriate nomenclature and the true type material of Palaeovaranus cayluxi and Palaeovaranus giganteus can serve as the basis for including these taxa into more complete phylogenetic analyses and comparing them with other coeval lizards from the Paleogene of Europe.

I admit that the taxonomic rearrangement I am here suggesting by setting the names Necrosaurus and Necrosauridae aside alters drastically the prevailed nomenclature of these lizards but this is necessary in order to follow the disciplines of the ICZN (1999) and maintain taxonomic stability. After all, similar cases are known also for other vertebrate groups, such as the usage of the crocodylian Boverisuchus Kuhn, 1938, over the "popular" but apparently invalid Pristichampsus Gervais, 1853 (Brochu, 2012). This highlights the need for the reassessment of taxa that were established during the
19 th century, as it is probable that "popular" names that are widely used in the modern literature will eventually prove to be nomina nuda or nomina dubia. Nevertheless, even the etymology of Palaeovaranus seems to be more appropriate than Necrosaurus: Filhol (1876) did not provide any explanation for the name Necrosaurus, although Molnar (2004) suggested that the name means "lizards of death". However, I believe that Filhol intended to signify in fact

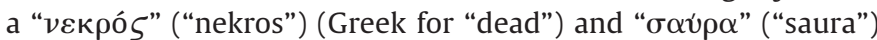
(Greek for "lizard"), i.e., a "dead lizard", which was a common practice of this author for several of his taxa from Quercy (e.g. Necrodasypus Filhol, 1894 and Necromanis Filhol, 1894). As such, I credit that the valid name Palaeovaranus (from the Greek " $\pi \alpha \lambda \alpha$ เó $\zeta$ " ["palaeos" = "old"] and the genus name Varanus) pays a more appropriate homage to this bizarre lizard, at least in comparison with the almost cynical name Necrosaurus.

\section{Conclusions}

Although Necrosaurus cayluxi was already identified as a large, fossil lizard since the 19th century (Filhol, 1873, 1876, 1877a, b, c), its exact taxonomic affinities are still unresolved. I here demonstrate that the current nomenclature of this animal is erroneous and that the appropriate name for this lizard from the Phosphorites of Quercy should be Palaeovaranus cayluxi and that authorship of this taxon should be attributed to Zittel (1887-1890) and not Filhol. This fact renders Zittel's (1887-1890) described and figured maxilla as the true holotype of this taxon and this specimen should serve as the basis of comparison of $P$. cayluxi with all other finds that have been previously assigned to "necrosaurids". Furthermore, the taxonomic status of Necrosaurus eucarinatus from the middle Eocene of Geiseltal, Germany, is clarified and it is demonstrated that it is a nomen dubium, whereas its sympatric Melanosauroides giganteus is shown to be a valid taxon, recombined under Palaeovaranus. The taxonomic content of Palaeovaranus is discussed and the genus includes remains that are known from the early Eocene until the early Oligocene of several localities in Europe. A new clade name, Palaeovaranidae, is herein established to encompass Palaeovaranus, though it is acknowledged that the relationships of this group need further assessment, especially in regard with certain North American and Asian forms. A thorough and more comprehensive reading of the old literature is highly advised, as it is expected that certain other species that were established during the 19th century will be eventually demonstrated to be nomina nuda.

\section{Disclosure of interest}

The author declares that he has no competing interest.

\section{Acknowledgements}

I am grateful to Jean-Claude Rage (MNHN) for his useful comments that enhanced the quality of this manuscript, for help with the old literature, and for his hospitality during my visit at MNHN for studying the Palaeovaranus specimens under his care. I also thank Walter Joyce (University of Fribourg) and Massimo Delfino (University of Torino) for their help and comments with zoological nomenclature. I wish also to thank Oliver Wings, Márton Rabi, and Michal Stache (GMH) for allowing me to study palaeovaranid material at GMH and permitting me to use the photographs of the holotypes of Ophisauriscus eucarinatus and Melanosauroides giganteus. Special thanks also to Oliver Rauhut (BSPG), Krisztina Sebe (University of Pécs), László Makádi (MFGI), and Zoltán Szentesi (HNHM) for information regarding the whereabouts of the holotype maxilla of Palaeovaranus cayluxi, Krister Smith (Senckenberg Research Institute, Frankfurt am Main) for information on 
Messel palaeovaranids, and Nour-Eddine Jalil (MNHN) for permission to use the photograph of the femur MNHN.F.QU17626. My visit to London and study of palaeovaranid specimens in NHMUK was made possible through support from SYNTHESYS GB-TAF-6591 and I thank Sandra Chapman (NHMUK) for access to such specimens under her care. I also acknowledge travel support from the University of Torino. I finally thank the Editor Romain Vullo and the two Reviewers, Jean-Claude Rage and Marc Augé, as their comments enhanced the quality of the manuscript.

\section{References}

Alifanov, V., 1993. Some peculiarties (sic) of the Cretaceous and Palaeogene lizard faunas of the Mongolian People's Republic. Kaupia 3, 9-13

Anquetin, J., Joyce, W.J., 2014. A reassessment of the Late Jurassic turtle Eurysternum wagleri (Eucryptodira, Eurysternidae). Journal of Vertebrate Paleontology 34, $1317-1328$.

Augé, M., 1986. Les Lacertiliens (Reptilia, Squamata) de l'Éocène supérieur et de l'Oligocène ouest européen. Thèse 3ème cycle Université Pierre et Marie Curie Paris VI (inédit), Paris.

Augé, M., 1990a. La faune de lézards et d'Amphisbènes de l'Éocène inférieur de Condé-en-Brie (France). Bulletin du Muséum national d'Histoire naturelle, $4^{\mathrm{e}}$ série 12, 111-141.

Augé, M., 1990b. La faune de lézards et d'Amphisbènes (Reptilia, Squamata) du gisement de Dormaal (Belgique, Éocène inférieur). Bulletin de l'Institut Royal des Sciences Naturelles de Belgique, Sciences de la Terre 60, 161-173.

Augé, M., 1993. Repartition et dynamisme des faunes de Lacertilia et d'Amphisbaenia dans l'Éocène Européen. Palaeovertebrata 22, 51-71.

Augé, M., 2003. La faune de Lacertilia (Reptilia, Squamata) de l'Éocène inférieur de Prémontré (Bassin de Paris, France). Geodiversitas 25, 539-574.

Augé, M., 2005. Évolution des lézards du Paléogène en Europe. Mémoires du Muséum national d'Histoire naturelle 192, 1-369.

Augé, M., Smith, R., 2009. An assemblage of early Oligocene lizards (Squamata) from the locality of Boutersem (Belgium), with comments on the Eocene-Oligocene transition. Zoological Journal of the Linnean Society 155, 148-170.

Bolet, A., 2017. First early Eocene lizards from Spain and a study of the compositional changes between late Mesozoic and early Cenozoic Iberian lizard assemblages. Palaeontologica Electronica 20.2.20A, 1-22.

Bolet, A., Rage, J.-C. Conrad, J.L., 2017. Rediscovery of the long-lost holotype of the lacertid lizard Pseudeumeces cadurcensis (Filhol, 1877). Journal of Vertebrate Paleontology 37, e1315669.

Borsuk-Białynicka, M., 1984. Anguimorphans and related lizards from the Late Cretaceous of the Gobi desert, Mongolia. Paleontologia Polonica. Results of the Polish-Mongolian Paleontological Expeditions, part X 46, 5-105.

Boulenger, G.A., 1918. Les Lezards Helodermatides de l'Eocène supérieur de la France. Comptes rendus hebdomadaires des séances de l'Académie des Sciences de Paris 166, 889-893.

Brochu, C., 2012. Phylogenetic relationships of Palaeogene ziphodont eusuchians and the status of Pristichampsus Gervais, 1853. Earth and Environmental Science Transactions of the Royal Society of Edinburgh 103, 1-30.

Broili, F., 1911. 3. Klasse. Reptilia. Reptilien. Kriechtiere. In: Zittel, K.A. (Ed.), Grundzüge der Paläontologie (Paläozoologie). II. Vertebrata. Druck und Verlag von R. Oldenbourg, Munich and Berlin, pp. 179-308.

Carroll, R.L., 1988. Vertebrate paleontology and evolution. W.H. Freeman and Company, New York.

Carroll, R.L., Debraga, M., 1992. Aigialosaurs: Mid-Cretaceous Varanoid lizards. Journal of Vertebrate Paleontology 12, 66-86.

Cifelli, R.L., Nydam, R.L., 1995. Primitive, helodermatid-like platynotan from the Early Cretaceous of Utah. Herpetologica 51, 286-291.

Cifelli, R.L., Nydam, R.L., Gardner, J.D., Weil, A., Eaton, J.G., Kirkland, J.I., Madsen, S.K., 1999. Medial Cretaceous vertebrates from the Cedar Moutain formation, Emery county, Utah: The Mussentuchit local fauna. In: Gillette, D.D. (Ed.), Vertebrate Paleontology in Utah, 99. Utah Geological Survey Miscellaneous Publication, pp. 219-242.

Conrad, J.L., 2008. Phylogeny and systematics of Squamata (Reptilia) based on morphology. Bulletin of the American Museum of Natural History 310, 1-182.

Conrad, J.L., Head, J.J., Carrano, M.T., 2014. Unusual soft-tissue preservation of a crocodile lizard (Squamata, Shinisauria) from the Green River Formation (Eocene) and shinisaur relationships. Anatomical Record 297, 545-559.

Conrad, J.L., Rieppel, O., Gauthier, J., Norell, M., 2011. Osteology of Gobiderma pulchrum (Monstersauria, Lepidosauria, Reptilia). Bulletin of the American Museum of Natural History 362, 1-88.

Conrad, J.L., Rieppel, O., Grande, L., 2008. Re-assessment of varanid evolution based on new data from Saniwa ensidens Leidy, 1870 (Squamata, Reptilia). American Museum Novitates 3630, 1-15.

De Stefano, G., 1903. I sauri del Quercy appartenenti alla collezione Rossignol. Atti della Societa Italiana di Scienze Naturali e del Museo Civili di Storia Naturale, Milan 42, 382-418.

De Stefano, G., 1905. Appunti sui Batraci e sui Rettili del Quercy appartenenti alla collezione Rossignol. Parte Terza. Coccodrilli-Serpenti-Tartarughe. Bolletino della Società Geologica Italiana 24, 17-67.
Duffaud, S., Rage, J.-C., 1997. Les remplissages karstiques polyphasés (Éocène, Oligocène, Pliocène) de Saint-Maximin (Phosphorites du Gard) et leur apport à la connaissance des faunes européennes, notamment pour l'Éocène moyen (MP 13). 2.-Systématique : Amphibiens et Reptiles. In: Aguilar, J.P., Legendre, S., Michaux, J. (Eds.), Actes du Congrès BiochroM'97. Mémoires et Travaux de l'Institut de Montpellier de l'École Pratique des Hautes Études 21, 729-735.

Dunn, E.R., 1927. Results of the Douglas Burden expedition to the Island of Komodo. I.-Notes on Varanus komodoensis. American Museum Novitates 286, 1-10.

Eastman, C.R., 1902. Text-book of Palaeontology. The MacMillan Company, New York.

Estes, R., 1964. Fossil vertebrates from the Late Cretaceous Lance Formation, eastern Wyoming. University of California Publications in Geological Sciences 49, 1-187.

Estes, R., 1983. Sauria Terrestria, Amphisbaenia. In: Wellnhofer, P. (Ed.), Encyclopedia of Paleoherpetology. Gustav Fisher Verlag, Stuttgart/New York.

Fejérváry, de G.J., 1918. Contributions to a monography on fossil Varanidae and on Megalanidae. Annales historico-naturales Musei nationalis hungarici 16, 341-467.

Fejérváry, de G.J., 1935. Further contributions to a monograph of the Megalanidae and Fossil Varanidae, with notes on recent varanians. Annales historiconaturales Musei nationalis hungarici, Pars Zoologica 29, 1-130.

Filhol, H., 1873. Sur les vertébrés fossiles trouvés dans les dépôts de phosphate de chaux du Quercy. Bulletin de la Société Philomathique de Paris, Série 6 (10), $85-89$.

Filhol, H., 1876. Sur les reptiles fossiles des phosphorites du Quercy. Bulletin de la Société Philomathique de Paris, Série 6 (11), 27-28.

Filhol, H., 1877a. Recherches sur les Phosphorites du Quercy. Étude des fossiles qu'on y rencontre et spécialement des mammifères. Pt. II. Annales des Sciences géologiques 8, 1-340.

Filhol, H., 1877b. Recherches sur les phosphorites du Quercy. Étude des fossiles qu'on y rencontre et spécialement des mammifères. G. Masson, Paris.

Filhol, H., 1877c. Recherches sur les Phosphorites du Quercy. Étude des fossiles qu'on y rencontre et spécialement des mammifères. Pt. II. Bibliothèque de l'École des hautes études, Section des Sciences naturelles 16, 1-338.

Filhol, H., 1894. Observations concernant quelques mammifères fossiles nouveaux du Quercy. Annales des Sciences Naturelles, Zoologie et Paléontologie 16, 129-150.

Gao, K.-Q., Norell, M.A., 1998. Taxonomic revision of Carusia (Reptilia: Squamata) from the Late Cretaceous of the Gobi Desert and phylogenetic relationships of anguimorphan lizards. American Museum Novitates 3230, 1-51.

Georgalis, G.L., Joyce, W.G., 2017. A review of the fossil record of Old World turtles of the clade Pan-Trionychidae. Bulletin of the Peabody Museum of Natural History $58,115-208$

Georgalis, G.L., Szyndlar, Z., Kear, B.P., Delfino, M., 2016. New material of Laophis crotaloides, an enigmatic giant snake from Greece, with an overview of the largest fossil European vipers. Swiss Journal of Geosciences 109, 103-116.

Georgalis, G.L., Villa, A., Delfino, M., 2017. The last European varanid: demise and extinction of monitor lizards (Squamata, Varanidae) from Europe. Journal of Vertebrate Paleontology 37, e1301946.

Gervais, P., 1853. Observations relatives aux reptiles fossiles de France (première partie). Comptes Rendus de l'Académie des Sciences de Paris 36, 374-377.

Gervais, P., 1876. Zoologie et Paléontologie générales. Arthus Bertrand, Paris.

Gilmore, C.W., 1928. The fossil lizards of North America. Memoirs of the National Academy of Sciences 11,1-197.

Gilmore, C.W., 1942. Paleocene faunas of the Polecat Bench Formation, Park County, Wyoming. Part II. Lizards. Proceedings of the American Philosophical Society 85, 159-167.

Haubold, H. 1977. Zur Kenntnis der Sauria (Lacertilia) aus dem Eozän des Geiseltals. In: Matthes, H.W., Thaler, B. (Eds.), Eozäne Wirbeltiere des Geiseltales (Wissenschaftliche Beiträge 1977/2), 1977. Martin-Luther-Universität HalleWittenberg, Wissenschaftliche Beiträge, pp. 107-112.

Haubold, H., Krumbiegel, G., 1984. Typenkatalog der Wirbeltiere aus dem Eozän des Geiseltals. Martin-Luther-Universität, Halle.

Hecht, M., Hoffstetter, R., 1962. Note préliminaire sur les amphibiens et les squamates du Landénien supérieur et du Tongrien de Belgique. Bulletin de l'Institut royal des Sciences naturelles de Belgique, Sciences de la Terre 38, 1-30.

Hoffstetter, R., 1943. Varanidae et Necrosauridae fossiles. Bulletin du Muséum national d'Histoire naturelle, Série 2 (15), 134-141.

Hoffstetter, R., 1946. Les Typhlopidae fossiles. Bulletin du Muséum National d'Histoire Naturelle, Série 2 (18), 309-315.

Hoffstetter, R., 1954. Sur la position systématique de Necrosaurus : Saurien de l'Éocène européen. Comptes Rendus Sommaires de la Société Géologique de France, Paris 1954, 422-424.

Hoffstetter, R., 1955. Squamates de type moderne. In: Piveteau, J. (Ed.), Traité de Paléontologie, 5. Masson, Paris, pp. 606-662.

Hoffstetter, R., 1962a. Additions à la faune reptilienne de l'Éocène supérieur de Mormont-Saint-Loup (Suisse). Bulletin de la Société Géologique de France 4, 109-117.

Hoffstetter, R., 1962b. Revue des récentes acquisitions concernant l'histoire et la systématique des Squamates. Problèmes actuels de paléontologie-Évolution des Vertébrés. Colloques internationaux du Centre national de la recherche scientifique 104, 243-279.

Hoffstetter, R., 1969. Présence de Varanidae (Reptilia, Sauria) dans le Miocène de Catalogne. Considérations sur l'histoire de la famille. Bulletin du Muséum National d'Histoire Naturelle 40, 1051-1064. 
Hong-Yu, Y., Norell, M.A., 2013. New materials of Estesia mongoliensis (Squamata: Anguimorpha) and the evolution of venom grooves in lizards. American Museum Novitates $3767,1-31$.

Houssaye, A., Bardet, N., Rage, J.-C., Pereda Suberbiola, X., Bouya, B., Amaghzaz, M., Amalik, M., 2011. A review of Pachyvaranus crassispondylus Arambourg 1952, a pachyostotic marine squamate from the latest Cretaceous phosphates of Morocco and Syria. Geological Magazine 148, 237-249.

International Commission on Zoological Nomenclature (ICZN), 1999. Internationa Code of Zoological Nomenclature, 4th edition. International Trust for Zoological Nomenclature, London, Online version http://www.iczn.org/iczn/index.jsp.

Keller, T., Schaal, S., 1992. Lizards: reptiles en route to success. In: Schaal, S., Ziegler, W. (Eds.), Messel: an insight into the history of life and of the earth. Clarendon press, Oxford, pp. 121-133.

Klembara, J., Green, B., 2010. Anguimorph lizards (Squamata, Anguimorpha) from the Middle and Upper Eocene of the Hampshire Basin of Southern England. Journal of Systematic Palaeontology 8, 97-129.

Kuhn, O., 1938. Die Crocodilier aus dem mittleren Eozän des Geiseltales bei Halle. Nova Acta Leopoldina 39, 313-328

Kuhn, O., 1939a. Die Schlangen (Boidae) aus dem Mitteleozän des Geiseltales. Nova Acta Leopoldina, Neue Folge 7, 119-133.

Kuhn, O., 1939b. Squamata: Lacertilia et Ophidia. Fossilium Catalogus, 1: Animalia, pars 86. Verlag Gustav Feller, Neubrandenburg, 89 p.

Kuhn, O., 1940a. Crocodilier-und Squamatenreste aus dem oberen Paleocän von Walbeck. Zentralblatt für Mineralogie, Geologie und Paläontologie, Abteilung B 1940, 21-25.

Kuhn, O., 1940b. Die Placosauriden und Anguiden aus dem Mittleren Eozän des Geiseltales. Nova Acta Academia Leopoldina 53, 461-486.

Kuhn, O., 1963. Sauria (Supplementum I). Fossilium Catalogus 1: Animalia, Pars 104 W. Junk. The Hague, 1-87.

Laurent, Y., Adnet, S., Bourdon, E., Corbalan, D., Danilo, L., Duffaud, S., Fleury, G., Garcia, G., Godinot, M., Le Roux, G., Maisonnave, C., Métais, G., Mourer-Chauviré, C., Presseq, B., Sigé, B., Solé, F., 2010. La Borie (Saint-Papoul, Aude) : un gisement exceptionnel dans l'Éocène basal du Sud de la France. Bulletin de la Société d'histoire naturelle de Toulouse 146, 89-103.

Lee, M.S., 1997. The phylogeny of varanoid lizards and the affinities of snakes. Philosophical Transaction of the Royal Society of London B 352, 53-91.

Lydekker, R., 1886. Indian Tertiary \& post-Tertiary Vertebrata. Siwalik Crocodilia, Lacertilia \& Ophidia. Palaeontologia Indica 3, 210-240

Lydekker, R., 1888a. Catalogue of Fossil Reptiles and Amphibians in the British Museum (Natural History). Part 1. The Orders Ornithosauria, Crocodilia, Dinosauria, Squamata, Rhynchocephalia, and Proterosauria. British Museum (Natural History), London.

Lydekker, R., 1888b. Notes on Tertiary Lacertilia and Ophidia. Geological Magazine $5,110-113$.

McDowell, S.B., Bogert, C.M., 1954. The systematic position of Lanthanotus and the affinities of the anguinomorphan lizards. Bulletin of the American Museum of Natural History 105, 1-145.

Meszoely, C., Estes, R., Haubold, H., 1978. Eocene anguid lizards from Europe and revision of the genus Xestops. Herpetologica 34, 156-166.

Molnar, R.E., 2004. 2. The long and honorable history of Monitors and their kin. In: Pianka, R.E., King, D., King, R.A. (Eds.), Varanoid Lizards of the World. Indiana University Press, Bloomington, Indiana, pp. 10-67.

Nessov, L.A., 1981. [The discovery of a terrestrial lizard jaw in the Upper Cretaceous of Uzbekistan]. Vestnik Leningradskogo Universiteta 2, 105-107 (in Russian).

Nessov, L.A., 1997. [Cretaceous Non-marine Vertebrates of Northern Eurasia]. Saint Petersburg State University, Institute of Earth Crust, Saint Petersburg (in Russian).

Nopcsa, F., 1908. Zur Kenntnis der fossilen Eidechsen. Beitrage zur Paläontologie und Geologie Osterreich-ungarns und des Orients 21,33-62.

Norell, M.A., Gao, K., 1997. Braincase and phylogenetic relationships of Estesia mongoliensis from the Late Cretaceous of the Gobi desert and the recognition of a new clade of lizards. American Museum Novitates 3211, 1-25.

Nydam, R.L., 2000. A new taxon of Helodermatid-like lizards from the Albian-Cenomanian of Utah. Journal of Vertebrate Paleontology 20, 285-294.

Pregill, G., Gauthier, J.A., Greene, H.W., 1986. The evolution of helodermatid squamates, with description of a new taxon and an overview of Varanoidea. Transactions of the San Diego Society of Natural History 21, 167-202.

Rage, J.-C., 1974. Les Serpents des Phosphorites du Quercy. Palaeovertebrata 6, 274-303.
Rage, J.-C., 1978. La poche à Phosphate de Ste-Néboule (Lot) et sa faune de vertébrés du Ludien supérior. 5. Squamates. Palaeovertebrata 8, 201-215.

Rage, J.-C., 1981. Les Colubridae (Reptilia, Serpentes) du Néogène français. Le problème des espèces du Miocène de Sansan. Geobios 14, 537-542.

Rage, J.-C., 1984a. La "Grande Coupure » Eocène-Oligocène et les herpétofaunes (Amphibiens et Reptiles) : problèmes du synchronisme des événements paléobiogéographiques. Bulletin de la Société géologique de France 26, 1251-1257.

Rage, J.-C., 1984b. Serpentes. In: Wellnhofer, P. (Ed.), Encyclopedia of paleoherpetology. Gustav Fisher Verlag, Stuttgart/New York.

Rage, J.-C., 1988. Le gisement du Bretou (Phosphorites du Quercy, Tarn-et-Garonne, France) et sa faune de vertébrés de l'Eocène supérieur. I Amphibiens et Reptiles. Palaeontographica Abteilung A 205, 3-27.

Rage, J.-C., 2006. The lower vertebrates from the Eocene and Oligocene of the Phosphorites du Quercy (France): an overview. In: Pélissié, T., Sigé, B. (Eds.), 30 millions d'années de biodiversité dynamique dans le paléokarst du Quercy. Journées Bernard Gèze. Strata, 13, pp. 161-173.

Rage, J.-C., 2013. Mesozoic and Cenozoic squamates of Europe. Palaeobiodiversity and Palaeoenvironments 93,517-534.

Rage, J.-C., Augé, M., 1993. Squamates from the Cenozoic of the western part of Europe. A review. Revue de Paléobiologie, volume spécial 7, 199-216.

Rage, J.-C., Augé, M., 2010. Squamate reptiles from the middle Eocene of Lissieu (France). A landmark in the middle Eocene of Europe. Geobios 43 , 253-268.

Rage, J.-C., Augé, M., 2015. Valbro: a new site of vertebrates from the early Oligocene (MP 22) of France (Quercy). III - Amphibians and squamates. Annales de Paléontologie 101, 29-41.

Rage, J.-C., Ford, R.L.E., 1980. Amphibians and squamates from the Upper Eocene of the Isle of Wight. Tertiary Research 3, 47-60.

Rieppel, O., 1980. The phylogeny of anguinomorph lizards. Denkschriften der Schweizerischen naturforschenden Gesellschaft 94, 1-86.

Rieppel, O., Conrad, J.L., Maisano, J.A., 2007. New morphological data for Eosaniwa koehni Haubold, 1977 and a revised phylogenetic analysis. Journal of Paleontology 81, 760-769.

Riley, H., Stutchbury, S., 1836. A description of various fossil remains of three distinct saurian animals discovered in the autumn of 1834, in the Magnesian Conglomerate on Durdham Down, near Bristol. Proceedings of the Geological Society of London 2, 397-399.

Rochebrune, de A.T., 1884. Faune ophiologique des Phosphorites du Quercy. Mémoires de la Société des Sciences naturelles de Saône-et-Loire 5, 149-164.

Roger, O., 1898. Wirbelthierreste aus dem Dinotheriensande. II. Theil. Bericht des Naturwissenschaftlichen Vereins für Schwaben und Neuburg in Ausburg 33, 385-396.

Romer, A.S., 1945. Vertebrate paleontology, Second edition. University Chicago Press, Chicago.

Romer, A.S., 1956. Osteology of the reptiles. University Chicago Press, Chicago.

Rossmann, T., 2000. Osteologische Beschreibung von Geiseltaliellus longicaudus Kuhn, 1944 (Squamata: Iguanoidea) aus dem Mittleren Eozän der Fossillagerstätten Geiseltal und Grube Messel (Deutschland), mit einer Revision de Gattung Geiseltaliellus. Palaeontographica Abteilung A 258, 117-158.

Smith, K.T. 2017. First crocodile-tailed lizard (Squamata: Pan-Shinisaurus) from the Paleogene of Europe. Journal of Vertebrate Paleontology 37, e1313743.

Smith, K.T., Gauthier, J.A., 2013. Early Eocene lizards of the Wasatch Formation near Bitter Creek, Wyoming: diversity and paleoenvironment during an interval of global warming. Bulletin of the Peabody Museum of Natural History 54, $135-230$.

Stritzke, R., 1983. Saniwa feisti n. sp., ein Varanide (Lacertilia, Reptilia) aus dem Mittel-Eozän von Messel bei Darmstadt. Senckenbergiana Lethaea 64, 497-508.

Vitt, L.J., Caldwell, J.P., 2014. Herpetology. An Introductory Biology of Amphibians and Reptiles, 4th ed. Academic Press, Elsevier, Amsterdam.

Weigelt, J., 1929. Loricotherium Waltheri ist doch kein Gürteltier, sondern eine Gürtlelechse: Placosaurus Waltheri n. sp. Jahrbuch des Halleschen Verbandes für die Erforschung der mitteldeutschen Bodenschätze 8, 187-191.

Weithofer, A., 1888. Beiträge zur Kenntniss der Fauna von Pikermi bei Athen Beiträge zur Paläontologie Österreich-Ungarns 6, 225-292.

Yadagiri, P., 1986. Lower Jurassic lower vertebrates from Kota Formation, PranhitaGodavari Valley, India. Journal of the Palaeontological Soceity of India 31, $89-96$.

Zittel, K.A., 1887-1890. Handbuch der Paläontologie. Palaeozoologie. III. Pisces, Amphibia, Reptilia, Aves. Druck und Verlag von R. Oldenbourg, Munchen/Leipsig. 